This manuscript has not been submitted for publication yet. Subsequent versions of the manuscript may therefore have slightly different content. If accepted, the final version of this manuscript will be available via the "Peer-reviewed Publication DOI" link on the right-hand side of this webpage. Please feel free to contact any of the authors; we welcome feedback. 


\title{
Seismic expression of shear zones: insights from 2-D convolution seismic modelling
}

\author{
T. Wrona ${ }^{1,2}$, H. Fossen ${ }^{3}$, I. Lecomte ${ }^{1}$, C.H. Eide $^{1} \&$ R.L. Gawthorpe ${ }^{1}$ \\ ${ }^{1}$ Department of Earth Science, University of Bergen, Allgaten 41, N-5007 Bergen, Norway. \\ ${ }^{2}$ Norwegian Academy of Science \& Letters, Drammensveien 78, 0271 Oslo, Norway. \\ ${ }^{3}$ Museum of Natural History, University of Bergen, Allgaten 41, N-5007 Bergen, Norway. \\ Email: thilo.wrona@uib.no
}

\begin{abstract}
During extension, compression or strike-slip motion, shear zones accommodate large amounts of strain in the crust. Our understanding of these processes critically depends on our ability to recognize shear zones in the subsurface. The exact signature of shear zones in seismic reflection data is however not well understood. To advance our understanding, we simulate how three outcrop examples of shear zones (Holsnøy, Cap de Creus, Borborema) would look in different types of seismic reflection data using 2-D convolution seismic modelling. We explore how geophysical effects (e.g. frequency, illumination) and geological properties (e.g. shear zone dip and aspect ratio) affect the seismic signature of shear zones. Our models show three consistent seismic characteristics of shear zones: (1) multiple, inclined reflections, (2) converging reflections and (3) cross-cutting reflections that can help interpreters recognizing these structures with confidence.
\end{abstract}

Keywords: Shear zones, ductile deformation, lower crust, seismic reflection data 


\section{Introduction}

Shear zones (i.e. volumes of rock with higher strain than the surrounding rocks) play an important role in accommodating deformation during rifting, continental break up and passive margin formation. Since strain contrasts often correlate with physical property changes, shear zones are expected to appear on seismic reflection data (e.g. Clerc et al., 2015; Phillips et al., 2016; Fazlikhani et al., 2017). Shear zone dimensions are well-documented (Tab. 1), but we still know relatively little about their signature in seismic reflection data. Recognizing shear zones in seismic data is however critical to our understanding of: (1) ductile deformation in the lower crust (Clerc et al., 2015), (2) strain distribution in crystalline basement (Fazlikhani et al., 2017) and (3) effects of preexisting structures (Phillips et al., 2016). For these reasons, we investigate the seismic signature of shear zones by 2-D convolution seismic modelling of outcrop examples.

\begin{tabular}{|c|c|c|c|c|c|c|}
\hline Location & Name & Thickness & Length & Displacement & Dip & Dip direction \\
\hline W Norway & Nordfjord-Sogn & $2-6 \mathrm{~km}^{1}$ & $120 \mathrm{~km}^{2}$ & $>50 \mathrm{~km}^{3}$ & $30-40^{\circ}$ & $\mathrm{W}^{2}$ \\
\hline SW Norway & Hardangerfjord & $5-6 \mathrm{~km}^{5}$ & $>600 \mathrm{~km}^{5}$ & $10-15 \mathrm{~km}^{5}$ & $22-23^{\circ 5}$ & $\mathrm{NW}^{5}$ \\
\hline W Norway & Bergen Arc & $2-3 \mathrm{~km}^{6}$ & $50 \mathrm{~km}^{6}$ & $>14 \mathrm{~km}^{6}$ & steep & $\mathrm{SW}^{6}$ \\
\hline W Norway & Holsn $\varnothing y$ & $30-150 \mathrm{~m}^{7}$ & $>10 \mathrm{~km}^{7}$ & - & - & $\mathrm{N}^{8}$ \\
\hline SW Norway & Stavanger & $1-2 \mathrm{~km}^{9}$ & $>200 \mathrm{~km}^{9}$ & - & $15-30^{\circ 9}$ & $\mathrm{~W}^{9}$ \\
\hline NW Spain & Cap de Creus & $20-300 \mathrm{~m}^{10}$ & $>10 \mathrm{~km}^{5}$ & - & - & NNE-SSW $^{10}$ \\
\hline Egypt & Ribha & $>200 \mathrm{~m}^{11}$ & $\sim 100 \mathrm{~km}^{11}$ & - & - & - \\
\hline Uganda & Nyamwamba & - & $\sim 50 \mathrm{~km}^{12}$ & - & - & - \\
\hline NW Namibia & Purros & $1-5 \mathrm{~km}^{13-15}$ & $620 \mathrm{~km}^{13-15}$ & - & $30-90^{\circ 13,16}$ & WSW-WNW ${ }^{13,16}$ \\
\hline NW Namibia & Three Palms & $1-2 \mathrm{~km}^{13}$ & $\sim 300 \mathrm{~km}^{13}$ & - & $10-90^{\circ 13,14,16}$ & $\mathrm{~W}, \mathrm{E}^{13,14,16}$ \\
\hline NE Brazil & Brasiliano & $100 \mathrm{~s} \mathrm{~m}^{18-20}$ & $100 \mathrm{~s} \mathrm{~km}^{18-20}$ & - & subvertical & - \\
\hline NE Brazil & Pernambuco & $2-5 \mathrm{~km}^{21}$ & $700 \mathrm{~km}^{21}$ & $\sim 11 \mathrm{~km}^{21}$ & $\geq 65^{\circ 21}$ & $\mathrm{NW}, \mathrm{SE}^{21}$ \\
\hline SE Brazil & Arcadia-Areal & $0.5-1 \mathrm{~km}^{22}$ & $\sim 700 \mathrm{~km}^{21}$ & - & $30-80^{\circ 22}$ & - \\
\hline New Zealand & Anita & $3.5-4 \mathrm{~km}^{23}$ & - & - & subvertical $^{22}$ & - \\
\hline
\end{tabular}

Table 1: Shear zone dimensions from: ${ }^{1}$ Johnston et al. (2007), ${ }^{2}$ Fossen $(2010),{ }^{3}$ Milnes et al. (1997), ${ }^{4}$ Norton (1986), ${ }^{5}$ Fossen and Hurich (2005), ${ }^{6}$ Wennberg et al. (1998), ${ }^{7}$ Austrheim (1990), ${ }^{8}$ Boundy et al. (1992), ${ }^{9}$ Phillips et al. (2016), ${ }^{10}$ Carreras (2001), ${ }^{11}$ Younes and McClay (2002), ${ }^{12}$ Koehn et al. (2016), ${ }^{13}$ Salomon et al. (2015), ${ }^{14}$ Goscombe and Gray (2008), ${ }^{15}$ Goscombe et al. (2003), ${ }^{16}$ Passchier et al. (2002), ${ }^{17}$ Foster et al. (2009), ${ }^{18}$ de Castro et al. (2012), ${ }^{19}$ de Castro et al. (2008), ${ }^{20}$ Kirkpatrick et al. (2013), ${ }^{21}$ Neves and Mariano (1999), ${ }^{22}$ Gontijo-Pascutti et al. (2010), ${ }^{23}$ Klepeis et al. (1999).

Seismic modelling is a technique that allows us to simulate the seismic response of geological structures. As such, we may regard this technique as a forward solution to the inverse problem of seismic interpretation, i.e. explaining the observed seismic image with a reasonable geological model. Seismic modelling is commonly used in 1-D to generate synthetic seismic traces by convolving reflectivity $\operatorname{logs}$ with wavelets in order to tie well to seismic data. While combining a series of 1$\mathrm{D}$ traces allows us to generate a 2-D seismic section from a geological model (e.g. Osagiede et al., 2014), the horizontal seismic resolution of the section is equal to the trace spacing (typically a few meters) bearing no physics of wave propagation. This approach perfectly resolve: (1) steeply dipping reflectors, (2) reflector ter- minations and (3) lateral property variations, which would be limited by the illumination (i.e. the ability to image dipping features) of these structures in nature.

To avoid these issues, we apply 2-D convolution seismic modelling (Lecomte et al., 2016), i.e. a 2-D convolution operator (i.e. the PointSpread Function or PSF) to a 2-D reflectivity model, which accounts for both: a complete resolution pattern and possibly limited illumination (Lecomte, 2008). The PSF is the diffraction-point response of an imaging system describing how much distortion is expected going from reflectivity to seismic data. As such, it contains information of the wavelet (e.g. frequency bandwidth) as well as the illumination. The illumination determines which parts of a geological structure are imaged at which (lat- 
eral) resolution. For example, steeply-inclined reflectors are often not imaged in seismic reflection data.

To investigate the seismic signature of shear zones, we apply 2-D convolution seismic modelling to three outcrop examples of shear zone from (1) Cap de Creus (Spain), (2) Holsnøy (Norway) and (3) Borborema (Brazil). We find that the seismic signature of shear zones depends on the complex interaction of a variety of geological and geophysical factors. Nevertheless, we are able to consistently identify three characteristic features of shear zones in our models: (1) multiple, inclined reflections, (2) converging reflections and (3) cross-cutting reflections. Moreover, we find that shear zones become difficult to identify when they are dipping steeper than the illumination of the seismic survey or when $50 \%$ of the data is noise. Finally, we find that curvature at the shear zone edge is a useful kinematic indicator, as seismic reflections forming an acute angle with the edge of the shear zone indicate movement towards the junction. These insights will hopefully help seismic interpreters to identify shear zones in seismic reflection data.

\section{Outcrop examples}

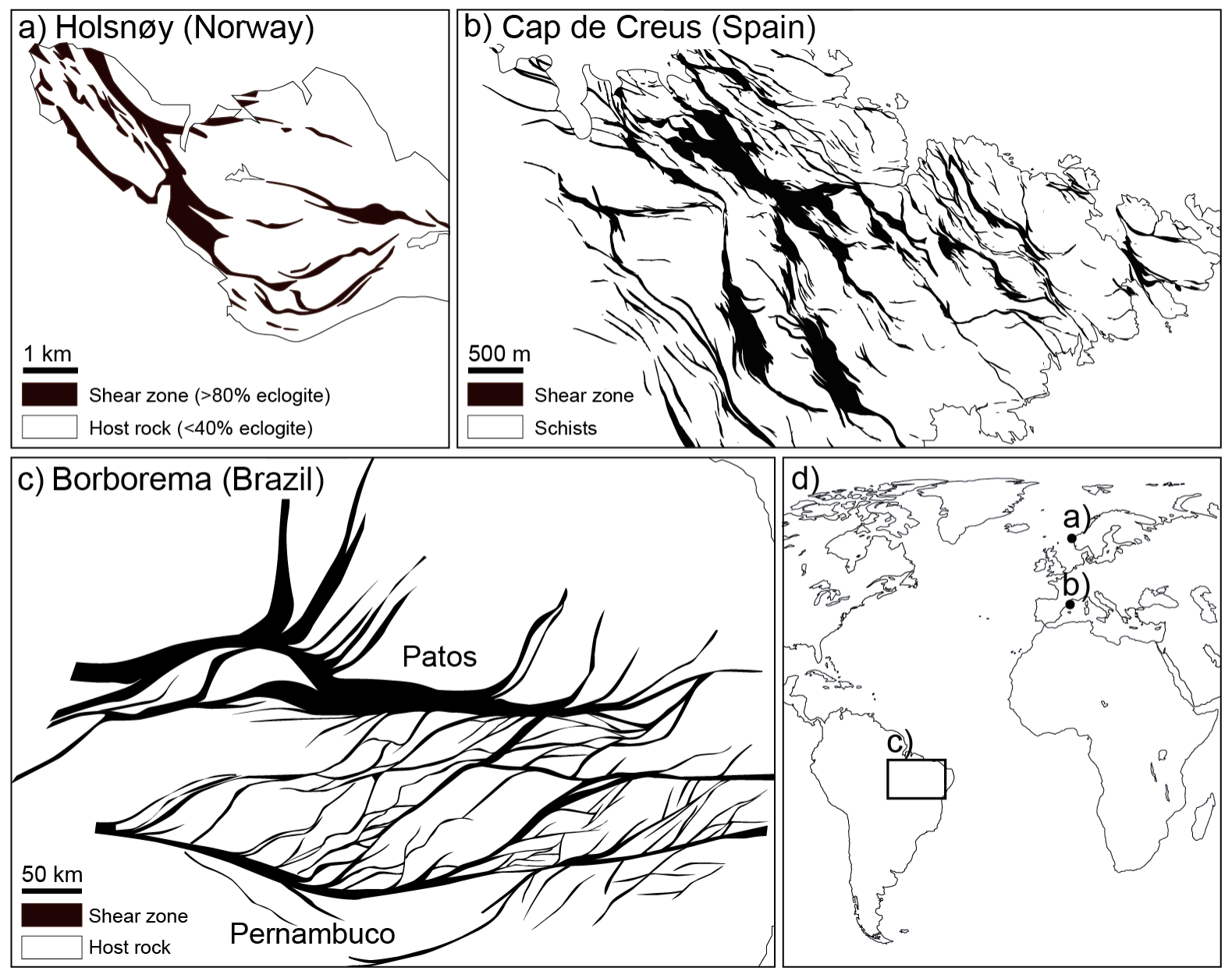

Figure 1: Outcrop examples of shear zone networks from: a) Holsnøy, Norway (Boundy et al., 1992; Austrheim et al., 1997); b) Cap de Creus, NE Spain (Carreras, 2001) and c) Borborema, Brazil (Neves and Mariano, 1999; Ganade de Araujo et al., 2014).

\subsection{Holsnøy (Norway)}

On Holsnøy (an island in western Norway) a network of eclogitized shear zones are exposed in a thrust sheet in the Caledonian oro- genic belt (Austrheim et al., 1997) (Fig. 1a). Geochronological data indicate that eclogitization and shear deformation occurred during the Caledonian (423 $\pm 4 \mathrm{Ma}$ ) (Bingen et al., 2004). 
As eclogization requires extremely high pressures $(\sim 18 \mathrm{kbar})$ and temperatures $\left(\sim 800^{\circ} \mathrm{C}\right)$, it is almost certain that these shear zones formed in the lower crust of Baltica subducting underneath Laurentia (Labrousse et al., 2010). At present day, these shear zones are exposed over an area of approximately $36 \mathrm{~km}^{2}$ (Fig. 1b). Shear zone thicknesses vary from 30 to $150 \mathrm{~m}$ in a continuous anastomosing pattern (Austrheim, 1990; Boundy et al., 1992). While the shear zones consist of eclogite facies rocks (omphacite + garnet + kyanite + epidote + phengite + quartz amphibole plagio- clase), the host rocks belong to the granulite facies (plagioclase + diopside + garnet scapolite orthopyroxene hornblende) (Austrheim and Griffin, 1985). These two rock units are typically separated by eclogite breccias consisting of blocks of granulites in foliate eclogites (Austrheim et al., 1997).

To build geological (reflectivity) models necessary for seismic modelling, we used the physical measurements of these rocks available at present day (Tab. 2). Ideally, these properties are as close as possible to the ones encountered at relevant depths in the subsurface.

\begin{tabular}{|c|c|c|c|c|c|c|c|c|c|c|}
\hline \multirow[t]{2}{*}{ Location } & \multirow[t]{2}{*}{ Rocks } & \multicolumn{3}{|c|}{ Bulk density $\left[\mathrm{g} / \mathrm{cm}^{3}\right]$} & \multicolumn{3}{|c|}{ P-wave vel. $[\mathrm{km} / \mathrm{s}]$} & \multicolumn{3}{|c|}{ S-wave vel. $[\mathrm{km} / \mathrm{s}]$} \\
\hline & & Min & Max & Avg & Min & Max & Avg & Min & Max & Avg \\
\hline \multirow[t]{2}{*}{ Cap de Creus } & Shear zone (Mylonite) & $2.86^{1}$ & $2.95^{1}$ & $2.91^{1}$ & $5.60^{2}$ & $6.70^{2}$ & $6.15^{2}$ & $4.60^{2}$ & $3.80^{2}$ & $4.20^{2}$ \\
\hline & Host rock (Schist) & $2.66^{3}$ & $2.72^{3}$ & $2.69^{3}$ & $5.60^{3}$ & $6.60^{3}$ & $6.10^{3}$ & $3.08^{3}$ & $3.51^{3}$ & $3.30^{3}$ \\
\hline \multirow[t]{2}{*}{ Holsn $\varnothing y$} & Shear zone (Eclogite) & $3.06^{4}$ & $3.33^{4}$ & $3.19^{4}$ & $8.30^{5}$ & $8.50^{5}$ & $8.40^{5}$ & $3.95^{6}$ & $4,33^{6}$ & $4,14^{6}$ \\
\hline & Host rock (Granulite) & $2.79^{4}$ & $3.21^{4}$ & $3.02^{4}$ & $7.50^{5}$ & $7.80^{5}$ & $7.65^{5}$ & $3,58^{6}$ & $4,16^{6}$ & $3,90^{6}$ \\
\hline \multirow[t]{2}{*}{ Borborema } & Shear zones (Mylonite) & $2.86^{1}$ & $2.95^{1}$ & $2.91^{1}$ & $5.60^{2}$ & $6.70^{2}$ & $6.15^{2}$ & $4.60^{2}$ & $3.80^{2}$ & $4.20^{2}$ \\
\hline & Host rock (Granite) & $2.50^{7}$ & $2.70^{7}$ & $2.60^{7}$ & $4.50^{7}$ & $6.00^{7}$ & $5.25^{7}$ & $2.50^{7}$ & $3.30^{7}$ & $2.90^{7}$ \\
\hline
\end{tabular}

Table 2: Physical rock properties used for seismic forward modelling from: ${ }^{1}$ Empirical relation $\left(v_{p} \rightarrow \rho\right)$ for mid to lower crustal rocks by Godfrey et al. (1997); ${ }^{2}$ Measurement of five mylonites by Mainprice and Casey (1990); ${ }^{3}$ Measurement of three schists by Godfrey et al. (2000); ${ }^{4}$ Bulk density measurements by Austrheim (1987); ${ }^{5} \mathrm{P}$-wave velocity measurements by Austrheim et al. (1997); ${ }^{6}$ Empirical relation $\left(v_{p} \rightarrow v_{s}\right)$ for granulate facies rocks and eclogites by Manghnani et al. (1974) and ${ }^{7}$ Typical physical properties of granites by Bourbi and Zinszner (1987)

\subsection{Cap de Creus (Spain)}

On Cap de Creus (a peninsula in northeast Spain), a Variscan shear belt exposes an extensive network of ductile shear zones (Carreras, 2001) (Fig. 1b). Although a subject of debate, these shear zones probably developed during progressive wrench-dominated deformation in the Variscan. As a result, they formed under retrograde metamorphic conditions in crystalline rocks with a pre-existing foliation. At present day, we can observe these shear zones over an area of $\sim 20 \mathrm{~km}^{2}$ (Fig. 1b). Shear zone thickness reach values of up to $300 \mathrm{~m}$ in continuous anastomosing patterns predominantly in crystalline schists (Carreras, 2001).

To build geological (reflectivity) models, we would ideally use the physical properties of these rocks encountered in the subsurface. As neither these nor present day measurements of these properties are available, we had to rely on physical properties typical for these types of rocks (mylonite, schist) in combination with empirical relations to constrain the bulk density, $\mathrm{P}$-wave and $\mathrm{S}$-wave velocity of the geological model (Tab. 2).

\subsection{Borborema Province (Brazil)}

The Borborema Province (northeast Brazil) hosts a network of larger and smaller shear zones, of which the largest ones reach about $10 \mathrm{~km}$ in thickness (Patos shear zone). The shear zones are late Neoproterozoic and related to the Brasiliano orogenic system (Ganade de Araujo et al., 2014; Neves and Mariano, 1999) (Fig. 1c). Kinematic and geochronological data indicate that the shear zone network formed during overall dextral strike-slip shearing in a transpressional setting at around 580570 Ma (Archanjo et al., 2002; Ganade de Araujo et al., 2014). This shear zone network covers almost the entire northeastern part of Brazil (Fig. 1c) and is considered to have continued on the African side prior to the South Atlantic breakup, and affect a variety of rocks, 
largely of granitic composition.

To our knowledge, relevant petrophysical measurements of these rocks are not available. We thus use typical physical properties typical for these types of rocks (mylonite, granite) in combination with empirical relations to derive the bulk density, P-wave and S-wave velocity (Tab. 2). Note that, while we aim to constrain these properties as well as possible, they may still differ from the original rock properties, simply because it is not possible to include all geological structures (e.g. mesoscale and microscale fabrics and lithological variations) in these models.

\section{2-D convolution seismic modelling}

To produce seismic images of shear zones, we use 2-D convolution seismic modelling (cf. Lecomte et al., 2016). This technique allows us to quickly generate zero-phase, pre-stack depth-migrated (PSDM) seismic images of geological models (Lecomte et al., 2015). In this study, we compare these images to 2-D seismic sections of crustal shear zones (e.g. Clerc et al., 2015; Phillips et al., 2016; Fazlikhani et al., 2017). Most studied outcrop examples of crustal shear zones (e.g. Holsnøy, Cap de Creus and Borborema) are however exposed in map view. To compare shear zones from outcrop to seismic observations, it was necessary to rotate these outcrop examples from map to crosssection view. This approach implicitly assumes structural similarity between strike-slip shear zones in map view and dip-slip shear zones in cross-section. For the Holsn $\varnothing y$ case, this is a matter of restoration to the original orientation of the shear zone network, which can be assumed to have been more horizontal based on the regional tilting of all units in the area (e.g. Fossen, 1993). For the Cap de Creus and Borborema cases, the shear zones developed in a strike-slip dominated setting, and rotation is not justified by their geological history. However, these and previous studies of shear zones show no systematic difference between tectonic regime and network geometry; geometric differences are rather controlled by coaxiality and strain (e.g. Gapais et al., 1987; Fossen and Cavalcante, 2017) in addition to rheological hetre- geneities in the initial rocks.

Once the geological models are built, we use 2-D convolution seismic modelling to generate the seismic images. While seismic reflection data depends on the complex interaction of a variety of geological and geophysical factors (e.g. Sheriff and Geldart, 1995; Yilmaz, 2001), we focus on the effects of the aspect ratio and dip of the shear zone as well as the seismic frequency and illumination in this study. At this point, it is probably worth highlighting that the vertical resolution of the seismic data is mainly a function of the frequency bandwidth of the signal and host rock velocity, while the lateral resolution primarily depends on signal frequency, host rock velocity and the illumination mentioned earlier. Both seismic resolutions typically decrease with depth, as the dominant frequency decreases downwards, primarily due to preferential absorption of high frequencies. Illumination is critical in seismic modelling, because it incorporates two common effects of seismic imaging: (1) that interfaces dipping more steeply than a certain angle cannot be imaged, and (2) that the lateral seismic resolution decreases under certain conditions (cf. Eide et al., 2018).

We apply 2-D convolution seismic modelling with the generic illumination described in Lecomte et al. (2016), i.e. the case with no specific survey design or overburden model. First, we extract the reflectivity as a 2-D grid according to a selected incident angle. Second, we select a series of parameters to design the PSF including: (1) a wavelet (characterized by its dominant frequency); (2) an average velocity in the zone to image; (2) an incident angle and (4) a maximum dip angle to be illuminated. Typical 3-D seismic surveys illuminate reflectors dipping up to $40^{\circ}$ or $50^{\circ}$ (Eide et al., 2018). Third, we apply the PSF to the 2-D reflectivity grid (in one run) to produce the PSDM seismic images. In this study, we use a normal incident angle (i.e. to simulate zerooffset acquisition), as for deep crustal structures (e.g. shear zones) even large offsets at the surface translate to small incident angles at depth (10-20 km). The maximum angle of dip to be illuminated, which we just call (maximum) illumination angle describes that only reflectors dipping below this angle will be vis- 
ible on the seismic images. This angle also af- tion is achieved for perfect illumination (i.e., a fects the lateral resolution; as a $45^{\circ}$ angle will maximum illumination angle of $90^{\circ}$ then correroughly correspond to about half a wavelength sponding to a quarter of a wavelength). lateral resolution. The optimal lateral resolu-

\begin{tabular}{llllll}
\multirow{2}{*}{ Location } & \multirow{2}{*}{ Year } & \multicolumn{4}{c}{ Dominant Frequency [Hz] } \\
\cline { 3 - 6 } & & Shallow & Medium & Deep & Very deep \\
\hline North Viking Graben, North Sea & 1998 & 54 & 48 & 29 & - \\
Egersund Basin, North Sea & 2005 & 45 & 30 & 15 & - \\
Northern North Sea & 2017 & 50 & 35 & 20 & 10 \\
Exmouth Basin, NW Australia & 2000 & - & 49 & 21 & - \\
Santos Basin, offshore Brazil & $2001 / 02$ & 35 & 25 & - & - \\
\hline
\end{tabular}

Table 3: Dominant frequencies covered by typical seismic reflection surveys (e.g. Osagiede et al., 2014). Depth levels correspond to 1 (shallow), 2 (medium), 4 (deep) and 8 (very deep) seconds two-way traveltime below the seafloor.
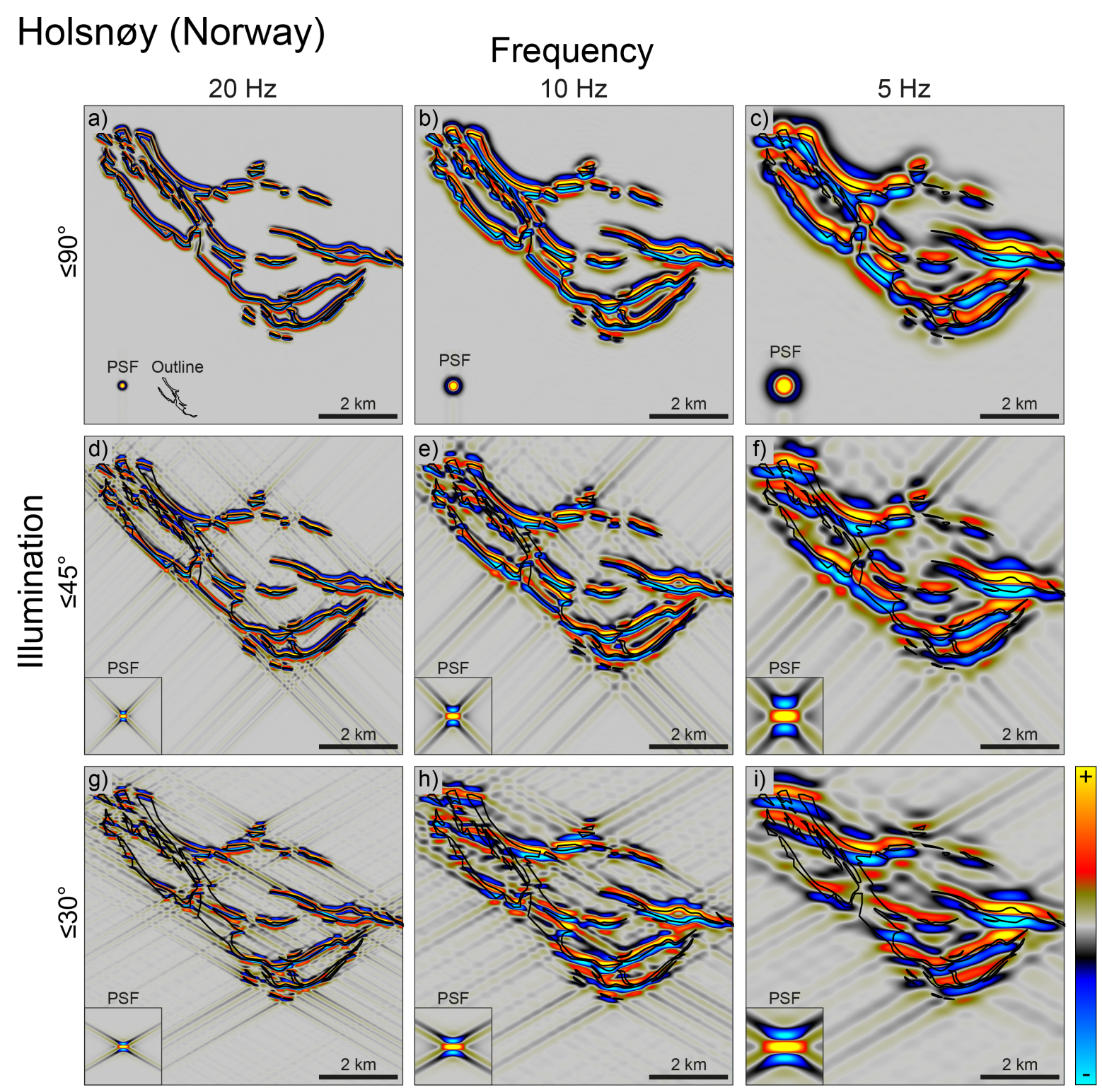

Figure 2: Seismic images of the Holsnøy shear zone (Norway) for different dominant frequen- 
cies $(10,20,40 \mathrm{~Hz})$ and maximum illumination angles $\left(30^{\circ}, 45^{\circ}, 90^{\circ}\right)$. The point-spread function (PSF) indicates the 2-D seismic resolution. The black outline shows the shear zone geometry. The colour bar is scaled to $50 \%$ of the maximum and minimum amplitudes.

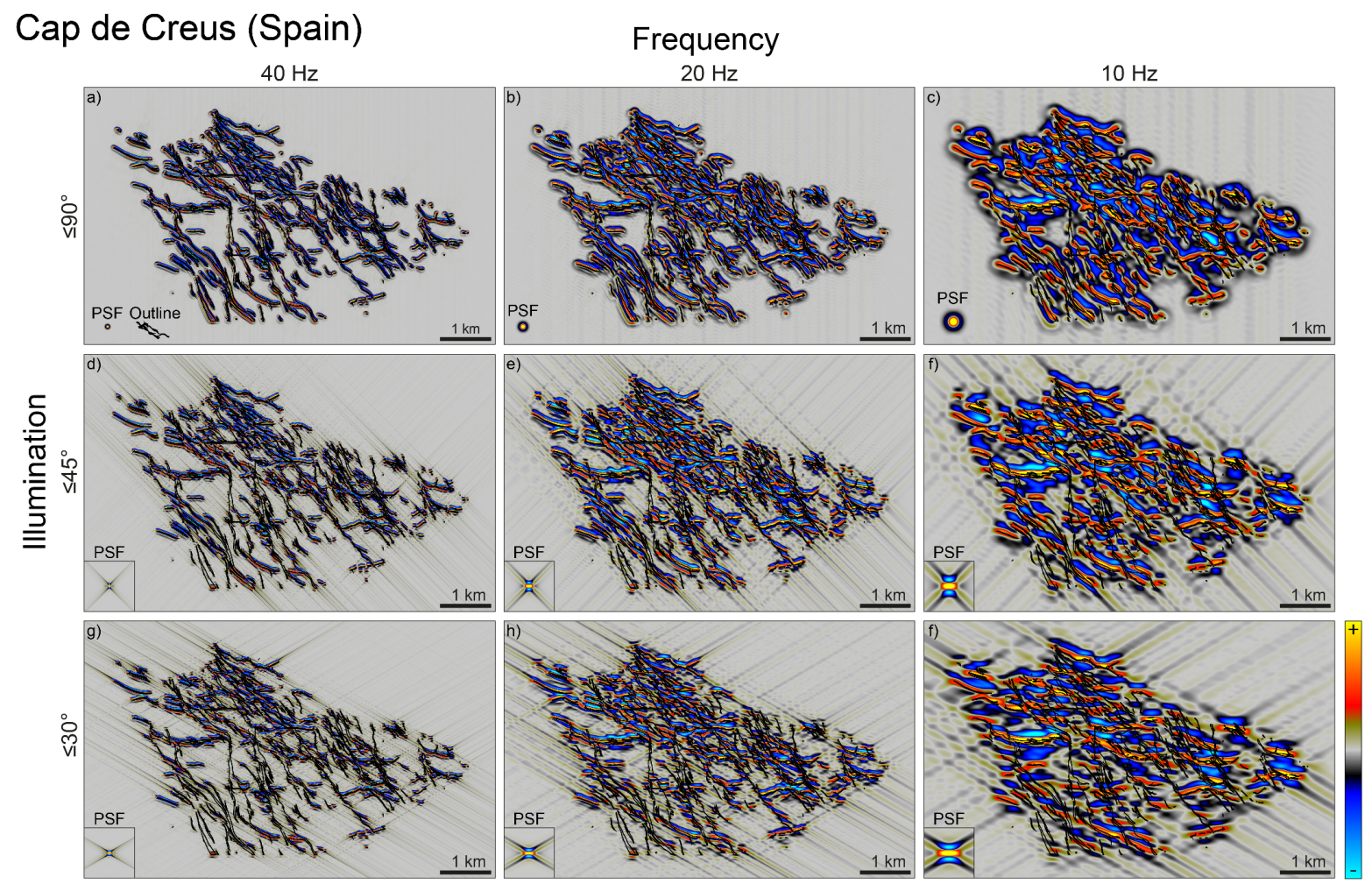

Figure 3: Seismic images of the shear zone network (Spain) for different dominant frequencies $(10,20,40 \mathrm{~Hz})$ and maximum illumination angles $\left(30^{\circ}, 45^{\circ}, 90^{\circ}\right)$. The point-spread function (PSF) indicates the 2-D seismic resolution. The black outline shows the shear zone geometry. The colour bar is scaled to $50 \%$ of the maximum and minimum amplitudes.

\subsection{Geophysical factors}

First, we explore how the seismic signature of shear zones changes dependent on the dominant frequency and maximum illumination angle of the seismic data. For this purpose, we generate seismic images of these three shear zone networks ranging from perfect to poor quality by systematically varying dominant frequencies (of Ricker wavelets) and maximum illumination angles (of the Point-Spread Function ) over a large range of values. This study includes models with maximum illumination angles ranging from 30 to 45 to $90^{\circ}$ and dominant frequencies varying from 5 to 10 to 20 $\mathrm{Hz}$ for the Holsnøy (Fig. 2); 10 to 20 to 40 $\mathrm{Hz}$ for the Cap de Creus (Fig. 3) and 5 to 10 to $15 \mathrm{~Hz}$ for the downscaled Borborema shear zone network (Fig. 4). These frequencies cover typical acquisition parameters of seismic reflection surveys for the considered depths (e.g. Osagiede et al., 2014) (Tab. 3). Moreover, we explore the effects of noise on the seismic signature of shear zones by systematically varying the noise, from a case without noise $(0 \%)$, via a case where a third of the amplitudes are noise $(33 \%)$ and a case of equal signal to noise $(50 \%)$ to a case with only noise (100\%) (Fig. 5).

\subsection{Geological factors}

Next, we explore how the seismic signature of these shear zones change in different geological settings. Again, while many geological factors can affect the seismic signature of shear zones, we focus on two parameters in this study: the aspect ratio and dip of the shear zone. To explore the effects of these parameters, we run 
models with aspect ratios of 1:1, 1:2 and 2:1 (i.e. the geometry, stretched to twice and compressed to half the original length), and rotated to dips of $0^{\circ}, 30^{\circ}$ and $60^{\circ}$ (Figs. 6-8). These values cover typical shear zone sizes and dips observed in the field (Tab. 1). Maximum il- lumination angles are set to $45^{\circ}$ and dominant frequencies to $10 \mathrm{~Hz}$ (Holsnøy), $20 \mathrm{~Hz}$ (Cap de Creus) and $10 \mathrm{~Hz}$ (Borborema) corresponding to moderate seismic imaging quality.

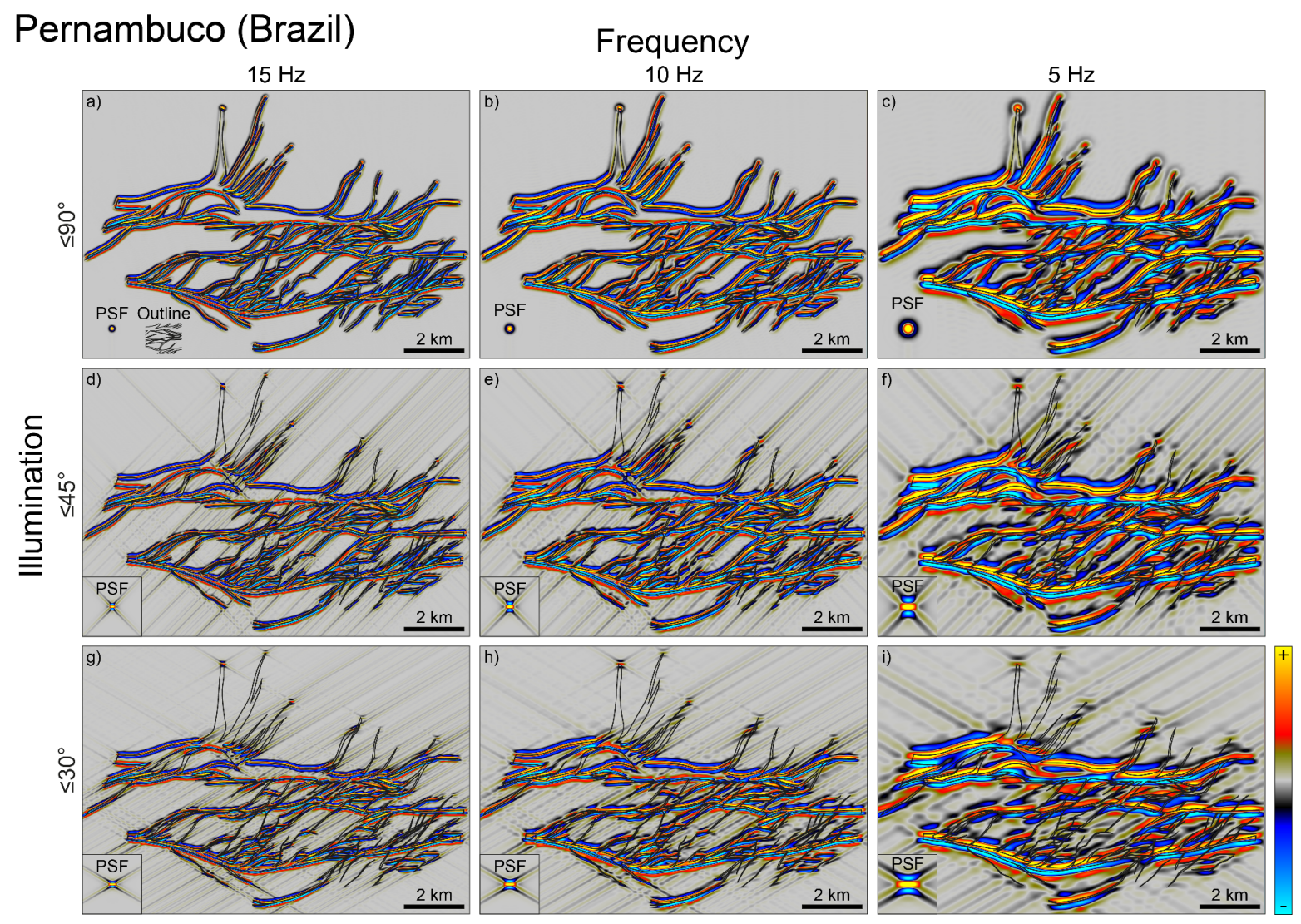

Figure 4: Seismic images of the Borborema shear zone network (Brazil) for different dominant frequencies $(10,20,40 \mathrm{~Hz})$ and maximum illumination angles $\left(30^{\circ}, 45^{\circ}, 90^{\circ}\right)$. The point-spread function (PSF) indicates the 2-D seismic resolution. The black outline shows the shear zone geometry. The colour bar is scaled to $50 \%$ of the maximum and minimum amplitudes. To compare the extremely-large Borborema shear zone to seismic studies, it was necessary to scale it down by a factor 50 .

\section{Results}

\subsection{Geophysical effects}

\subsubsection{Holsnøy (Norway)}

Our first set of models shows the seismic signature of the Holsnøy shear zone network for different dominant frequencies $(5,10,20 \mathrm{~Hz})$ and illumination angles $\left(30,60,90^{\circ}\right)$ (Fig. 2). At high frequency $(20 \mathrm{~Hz})$ and perfect illumination $\left(90^{\circ}\right)$, we obtain a perfect image of the shear zone with clearly-separable seismic reflections of each high strain area (Fig. 2a). At intermediate frequency $(10 \mathrm{~Hz})$ and perfect illumination $\left(90^{\circ}\right)$, we start to lose some details, as reflections begin to merge vertically and horizontally (Fig. 2b). Nonetheless, we are still able to image the entire shear zone. At low frequency $(5 \mathrm{~Hz})$ and perfect illumination $\left(90^{\circ}\right)$, we have lost most of the details: (1) thin reflections have disappeared, (2) closely spaced reflections merged and (3) reflection terminations appear as amplitude anomalies (Fig. 2c). At this point, we can identify: (1) the overall shape, (2) orientation and (3) some internal intersections of the shear zone. At intermediate 
illumination $\left(45^{\circ}\right)$, steeper geometries show lower amplitudes and fewer anomalies (Fig. $2 \mathrm{~d}-\mathrm{f})$. This effect continues for low illumination $\left(30^{\circ}\right)$, where inclined reflections disappear.
At this stage, we can only see a few disjointed sub-horizontal reflections (Fig. 2g-i).

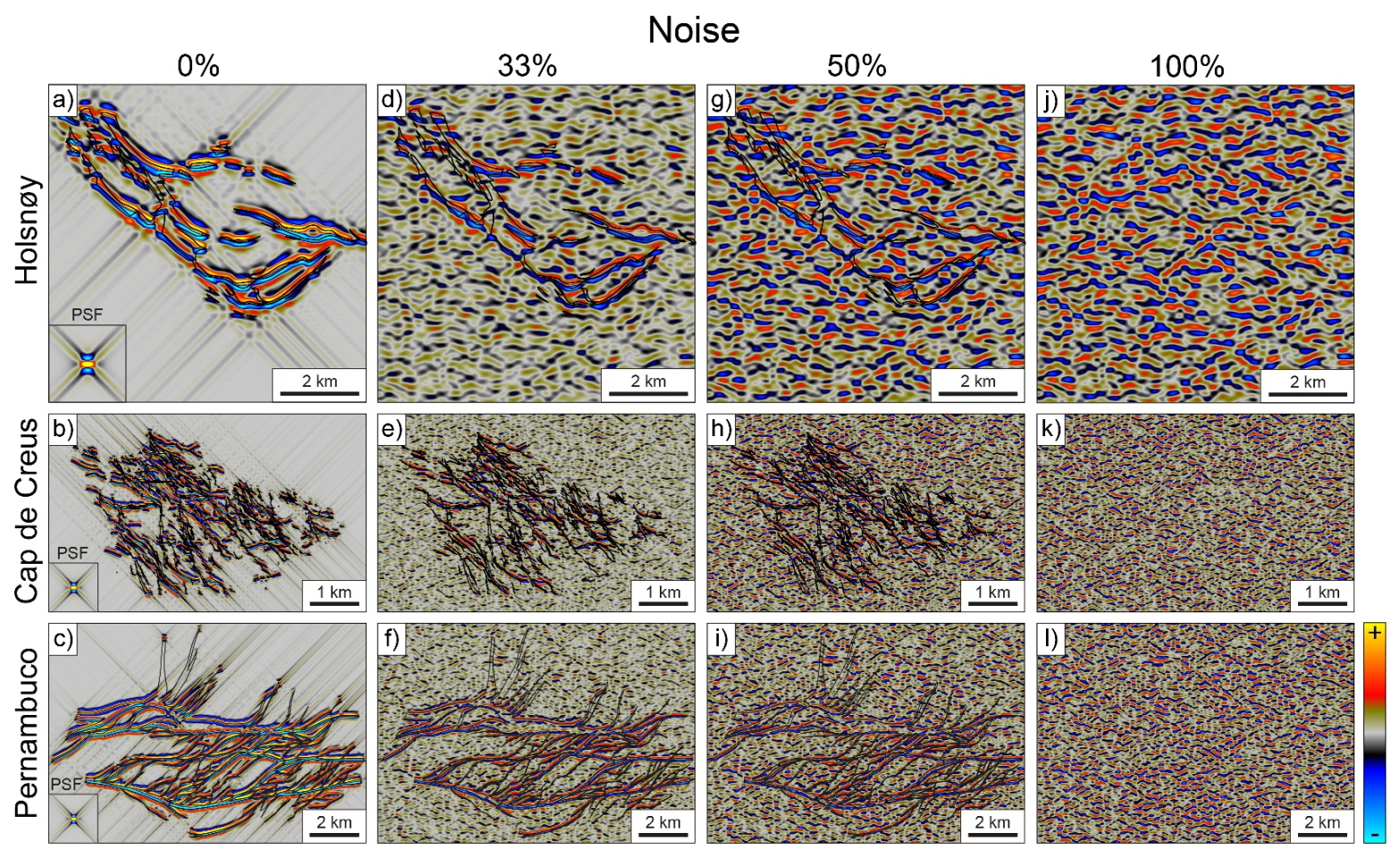

Figure 5: Seismic images of the Holsnøy (a-d), Cap de Creus (e-h) and Borborema shear zone (i-l) for different levels of noise $(0 \%, 33 \%, 50 \%$ and 100\%). The point-spread function (PSF) indicates the 2-D seismic resolution. The black outline shows the shear zone geometry. The colour bar is scaled to $50 \%$ of the maximum and minimum amplitudes. To compare the extremely-large Borborema shear zone to seismic studies, it was necessary to scale it down by a factor 50 .

\subsubsection{Cap de Creus (Spain)}

Our second set of models shows the seismic signature of the Cap de Creus shear zone network for different dominant frequencies $(10,20,40$ $\mathrm{Hz})$ and illumination angles $\left(30,60,90^{\circ}\right)$ (Fig. $3)$. At very high frequency $(40 \mathrm{~Hz})$ and perfect illumination $\left(90^{\circ}\right)$, we obtain a perfect image of the shear zone with clearly-separable seismic reflections of each high strain area (Fig. $3 a)$. At high frequency $(20 \mathrm{~Hz})$ and perfect illumination $\left(90^{\circ}\right)$, we start to lose some details, as reflections begin to merge vertically and horizontally (Fig. 3b), yet we are still able to image the entire shear zone. At intermediate frequency $(10 \mathrm{~Hz})$ and perfect illumination $\left(90^{\circ}\right)$, we have lost most of the details: (1) thin reflections have disappeared, (2) closely spaced reflections merged and (3) reflection terminations appear as amplitude anomalies (Fig. 3c). At this point, we can identify: (1) the overall shape, (2) orientation and (3) some internal intersections of the shear zone. At intermediate illumination $\left(45^{\circ}\right)$, steeper geometries show lower amplitudes and fewer anomalies (Fig. 3d-f). This effect continues for low illumination $\left(30^{\circ}\right)$, where inclined reflections disappear. At this stage, we can only see a few criss-crossing reflections (Fig. 3g-i).

\subsubsection{Borborema (Brazil)}

Our third set of models shows the seismic signature of the downscaled Borborema shear zone network for different dominant frequencies $(5,10,15 \mathrm{~Hz})$ and illumination angles 
$\left(30,60,90^{\circ}\right)$ (Fig. 4). At high frequency (15 $\mathrm{Hz}$ ) and perfect illumination $\left(90^{\circ}\right)$, we obtain a perfect image of the shear zone with clearlyseparable seismic reflections of each high strain area (Fig. 4a). At intermediate frequency (10 $\mathrm{Hz}$ ) and perfect illumination $\left(90^{\circ}\right)$, we still see most of the details, despite reflections becoming wider (Fig. 4b). At low frequency $(5 \mathrm{~Hz})$ and perfect illumination $\left(90^{\circ}\right)$, we start to lose some of the details: (1) thin reflections disappear, (2) closely spaced reflections become merged and (3) reflection terminations appear as amplitude anomalies (Fig. 4c), yet we can still identify: (1) the overall shape, (2) orientation and (3) some internal intersections of the shear zone. At intermediate illumination $\left(45^{\circ}\right)$, steeper geometries start to disappear (Fig. 4df). This effect continues for low illumination $\left(30^{\circ}\right)$, where inclined reflections completely disappear. At this stage, we can only see a few sub-horizontal reflections (Fig. 4g-i).

\section{Holsnøy (Norway)}
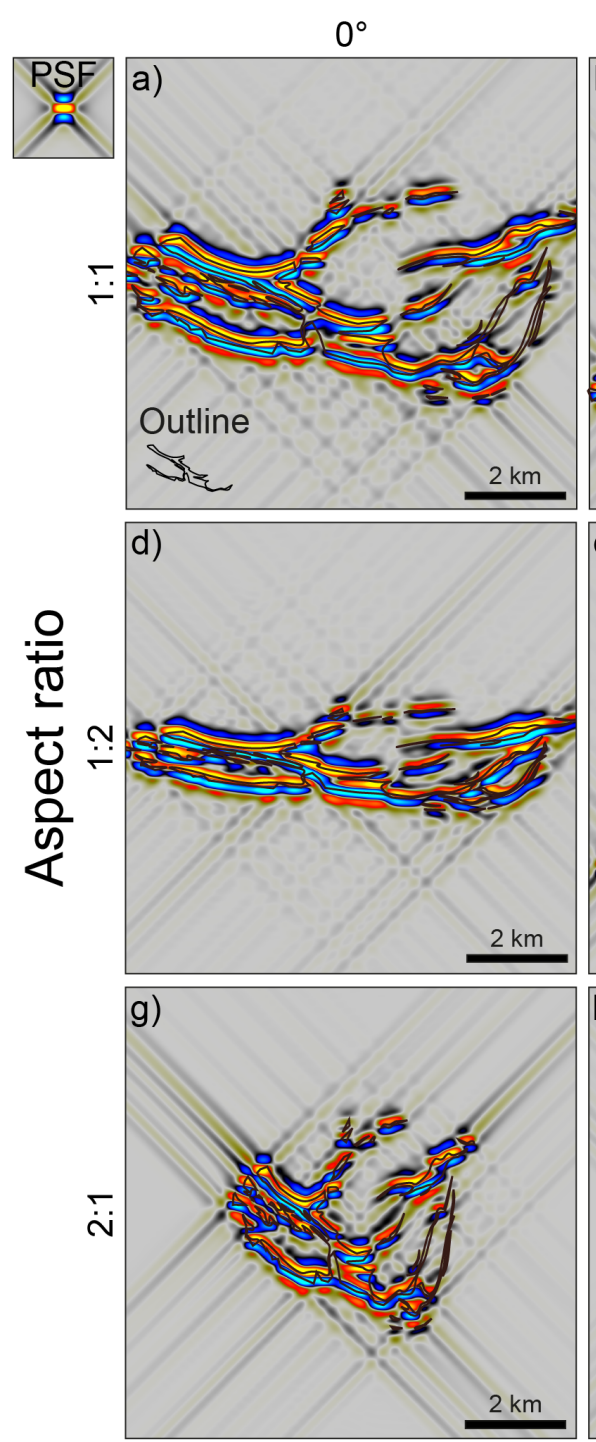
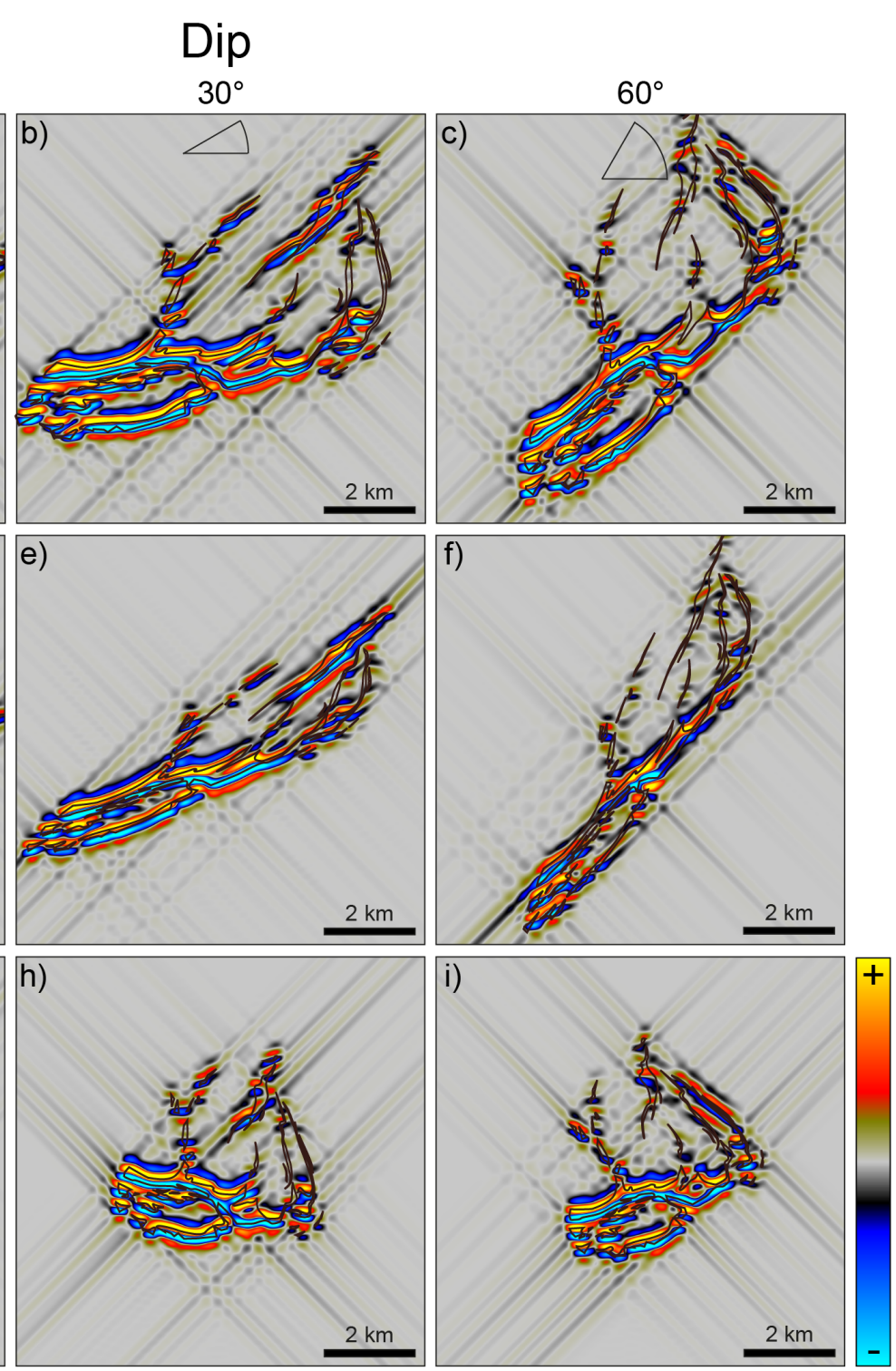

Figure 6: Seismic images of the Holsnøy shear zone (Norway) for different dips $\left(0^{\circ}, 30^{\circ}, 60^{\circ}\right)$ and aspect ratios $(1: 1,1: 2,2: 1)$ create with intermediate frequency $(10 \mathrm{~Hz})$ and illumination $\left(45^{\circ}\right)$. The point-spread function (PSF) indicates the 2-D seismic resolution. The black outline shows the shear zone geometry. The colour bar is scaled to $50 \%$ of the maximum and minimum amplitudes. 

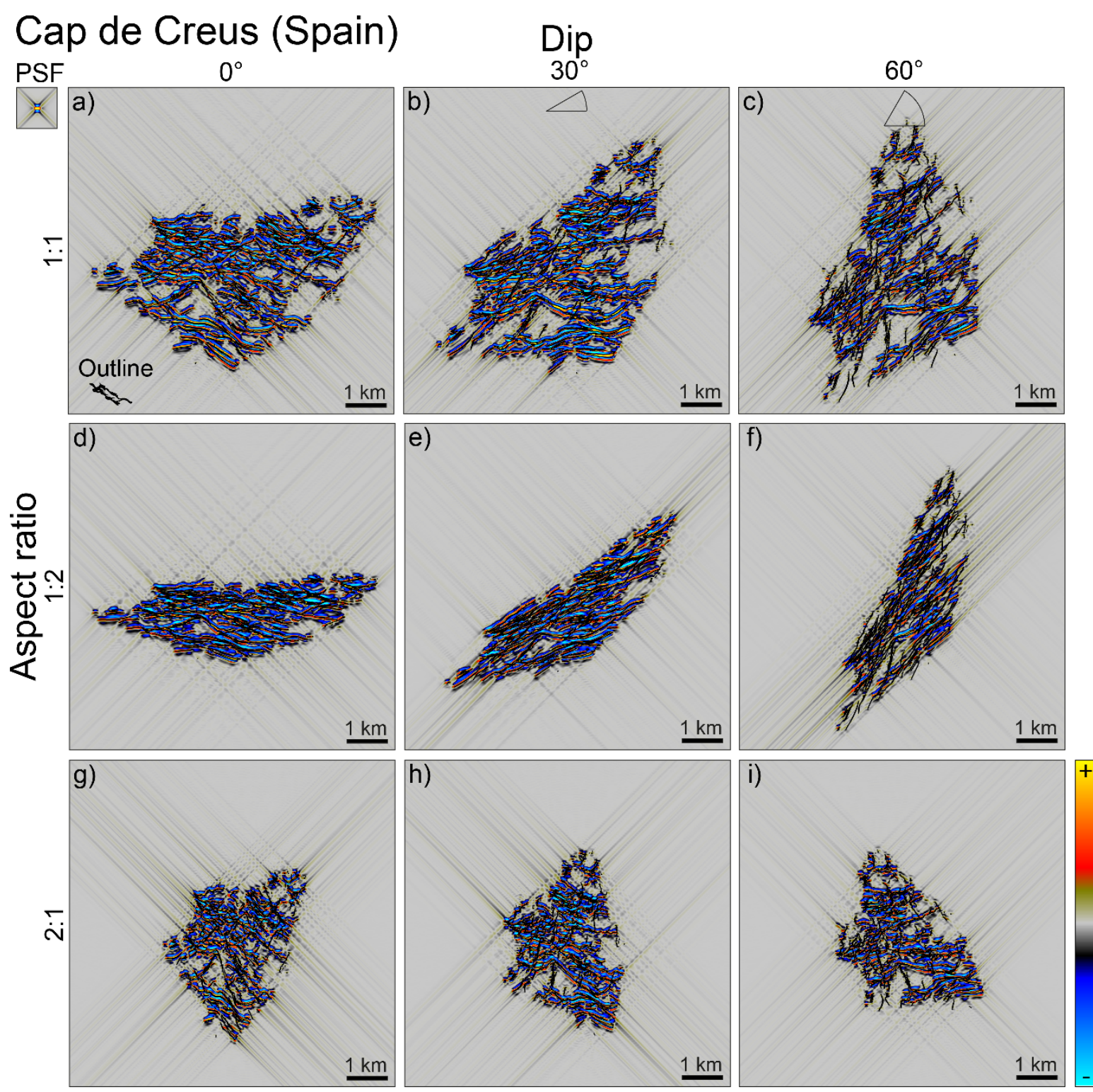

Figure 7: Seismic images of the Cap de Creus shear zone (Spain) for different dips $\left(0^{\circ}, 30^{\circ}, 60^{\circ}\right)$ and aspect ratios $(1: 1,1: 2,2: 1)$ create with intermediate frequency $(10 \mathrm{~Hz})$ and illumination $\left(45^{\circ}\right)$. The point-spread function (PSF) indicates the 2-D seismic resolution. The black outline shows the shear zone geometry. The colour bar is scaled to $50 \%$ of the maximum and minimum amplitudes.

\subsubsection{Seismic noise}

Our fourth set of models show the seismic signature of the Holsnøy, Cap de Creus and Borborema shear zone for different noise levels $(0 \%, 33 \%, 50 \%, 100 \%)$. Without noise, these models are the same as the intermediate imaging ones (Figs. 2e,3e,4e). These models show clear images of the shear zones, illuminating all reflections dipping below $45^{\circ}$ (Fig. 5a-c). At $33 \%$ noise, it becomes difficult to identify some of the thinner parts of the shear zones, as their amplitudes are on the same level as the noise (Fig. 5d-f). At 50\% noise, it is difficult to identify shear zones (Fig. 5g-i), as the seismic image becomes increasingly similar to the ones with $100 \%$ noise (Fig. 5j-1). 

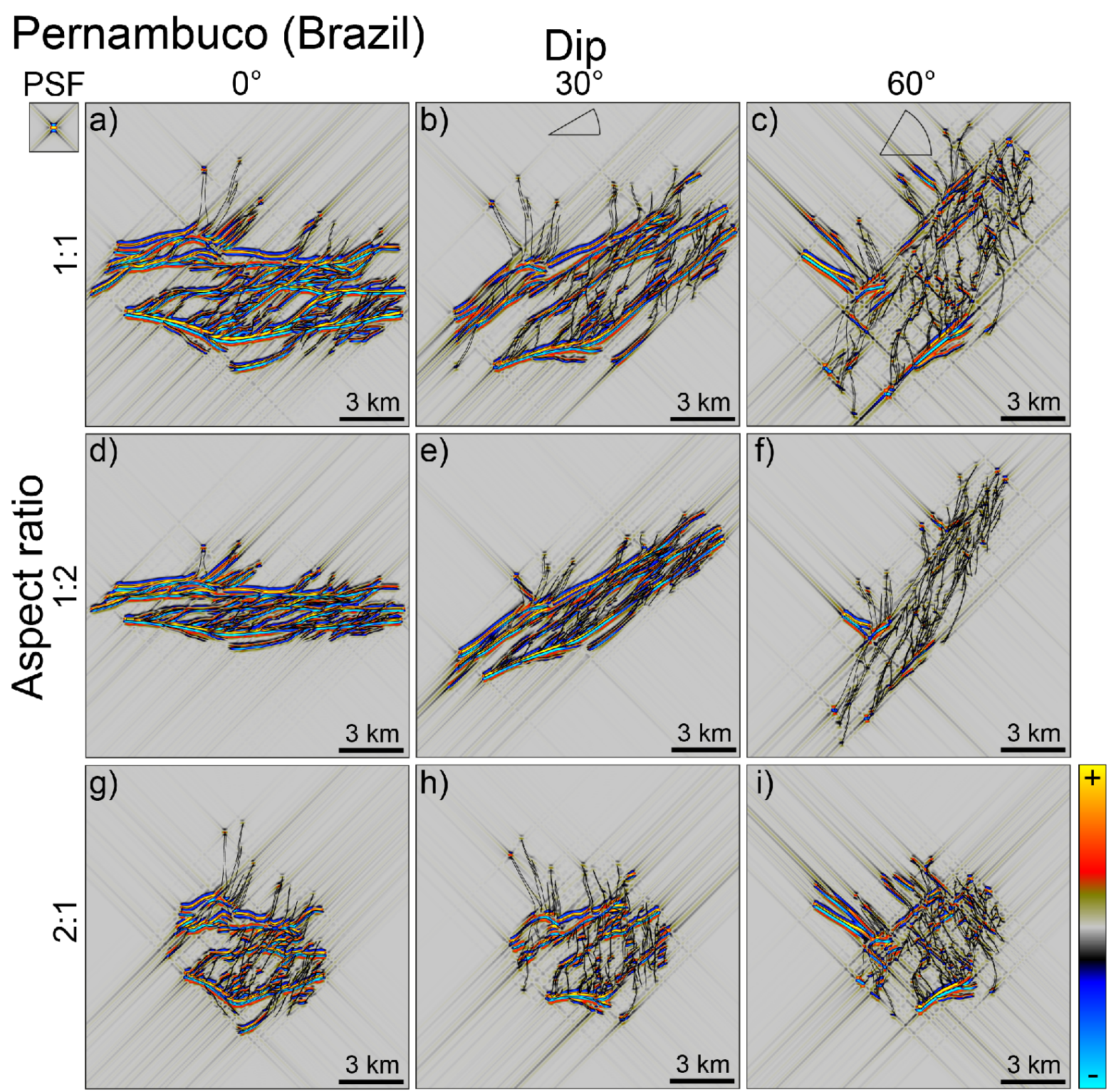

Figure 8: Seismic images of the Borborema shear zone (Brazil) for different dips $\left(0^{\circ}, 30^{\circ}, 60^{\circ}\right)$ and aspect ratios $(1: 1,1: 2,2: 1)$ create with intermediate frequency $(10 \mathrm{~Hz})$ and illumination $\left(45^{\circ}\right)$. The point-spread function (PSF) indicates the 2-D seismic resolution. The black outline shows the shear zone geometry. The colour bar is scaled to $50 \%$ of the maximum and minimum amplitudes. To compare the extremely-large Borborema shear zone to seismic studies, it was necessary to scale it down by a factor 50 .

\subsection{Geological effects}

\subsubsection{Holsn $\varnothing y$ (Norway)}

Our fifth set of models shows the seismic signature of the Holsnøy shear zone network for different aspect ratios $(1: 1,1: 2,2: 1)$ and dips $\left(0^{\circ}, 30^{\circ}, 60^{\circ}\right)$ (Fig. 6). At $1: 1$ aspect ratio and no dip, we obtain a good seismic image of the shear zone clearly showing all parts (Fig. 6a). As we increase the dip to $30^{\circ}$ (Fig. 6b) and $60^{\circ}$ (Fig. 6c), we start to lose some of the steeper dipping reflections. At 1:2 aspect ratio, seismic reflections become closer and merge vertically (Fig. 6d-f). At $60^{\circ}$ dip, it becomes difficult to identify the shear zone, as we only image a few sub-parallel reflections (Fig. 6f). At 2:1 aspect ratio, we image most parts of the shear zone, only losing some inclined reflections at $30^{\circ}$ and $60^{\circ}$ dip (Fig. 6g-i). 


\subsubsection{Cap de Creus (Spain)}

Our fifth set of models shows the seismic signature of the Cap de Creus shear zone network for different aspect ratios $(1: 1,1: 2,2: 1)$ and dips $\left(0^{\circ}, 30^{\circ}, 60^{\circ}\right)$ (Fig. 7 ). At $1: 1$ aspect ratio, $0^{\circ}$ and $30^{\circ}$ dip, we obtain a good seismic image of the shear zone clearly showing all parts (Fig. 7a,b). At $60^{\circ}$ dip, we start to lose some of the inclined reflections (Fig. 7c). At 1:2 aspect ratio, seismic reflections become closer and merge vertically (Fig. 7d-f). At $60^{\circ}$ dip, it becomes difficult to identify the shear zone, as we only image a few sub-parallel reflections (Fig. 7f). At 2:1 aspect ratio, we image most parts of the shear zone, only losing some inclined reflections at $30^{\circ}$ and especially at $60^{\circ}$ dip (Fig. 7g-i).

\subsubsection{Borborema (Brazil)}

Our fifth set of models shows the seismic signature of the Borborema shear zone network for different aspect ratios $(1: 1,1: 2,2: 1)$ and $\operatorname{dips}\left(0^{\circ}, 30^{\circ}, 60^{\circ}\right)$ (Fig. 8). At $1: 1$ aspect ratio and no dip, we obtain a good seismic image of the shear zone clearly showing all parts (Fig. 8a). At $30^{\circ}$ and especially $60^{\circ}$ dip, it becomes difficult to identify the shear zone, as we have lost most the inclined reflections (Fig. 8b,c). At $1: 2$ aspect ratio, $0^{\circ}$ and $30^{\circ}$ dip, seismic reflections become closer and merge vertically (Fig. 8d,e). At $60^{\circ}$ dip, we have lost almost all reflections and it becomes impossible to identify the shear zone (Fig. 8f). At 2:1 aspect ratio and no dip, we image most parts of the shear zone (Fig. 8g), but at $30^{\circ}$ and especially $60^{\circ} \mathrm{dip}$, it becomes difficult to impossible to identify the shear zone, as we have most inclined reflections (Fig. 8h, i).

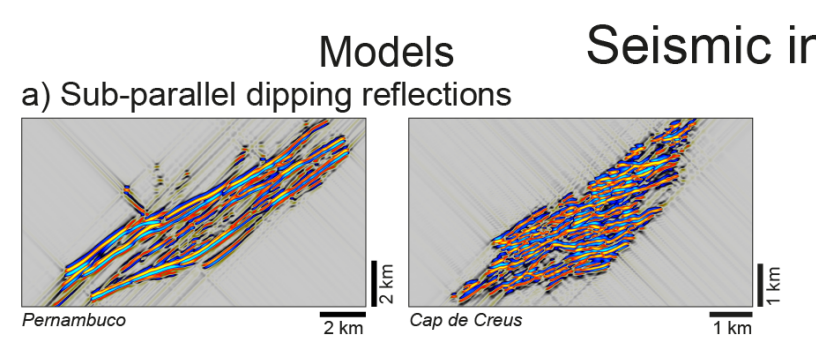

b) Cross-cutting reflections

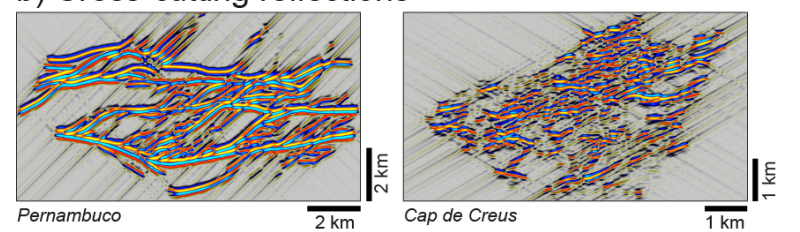

c) Unidirectional reflection junctions
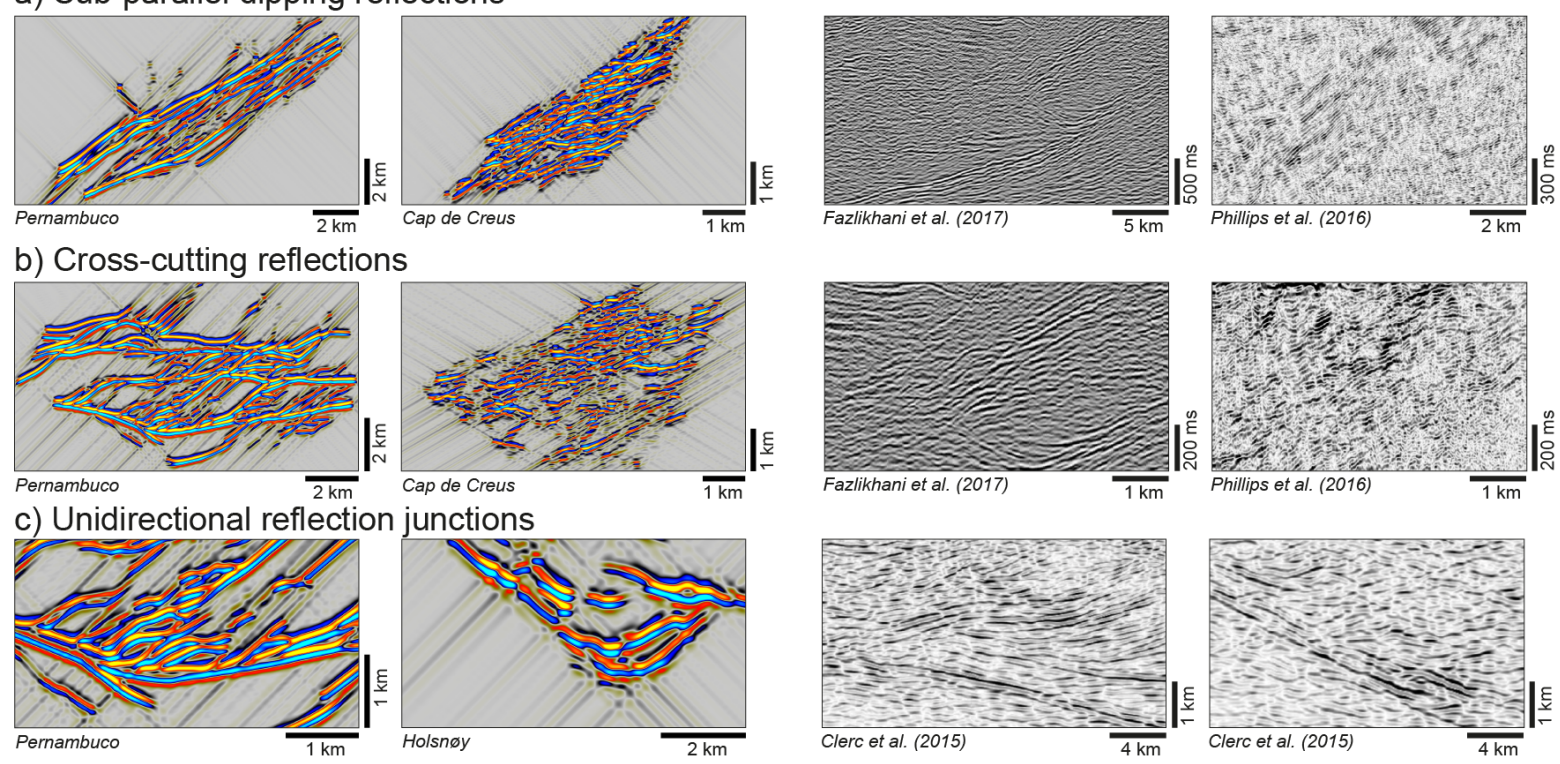

Figure 9: Seismic indicators of crustal shear zones in our models and seismic observations (Clerc et al., 2015; Phillips et al., 2016; Fazlikhani et al., 2017).

\section{Discussion}

\subsection{Seismic indicators}

Kilometre-scale shear zones are commonly interpreted in seismic reflection data as subparallel inclined reflections (e.g. Clerc et al., 2015;
Phillips et al., 2016; Fazlikhani et al., 2017). Our models show that such shear zones observed in the field can indeed produce subparallel, inclined seismic reflections given that their dip does not exceed the maximum illumination of the seismic survey (Fig. 9a). The problem is however that other geological struc- 
tures, such as tilted layers or magmatic dykes can also produce similar subparallel, inclined reflections (e.g. Phillips et al., 2018). To differentiate shear zones from tilted layers, we suggest to search for cross-cutting seismic reflections. Many of our models show cross-cutting seismic reflections resulting from intersections of different strands of these shear zone networks (e.g. Fig. 9b). This is interesting as cross-cutting reflections are usually associated with magmatic intrusions intersecting the host strata (e.g. Hansen et al., 2004; Planke et al., 2005; Magee et al., 2014). To differentiate shear zones from magmatic intrusions, we suggest to analyse reflection junctions. Our models show several seismic reflections consistently converging in the same direction towards the edge of the shear zone forming large-scale lenses (e.g. Fig 9c). In contrast, networks of magmatic intrusions commonly show reflections converging in various directions forming stacked sill complexes (e.g. Magee et al., 2014; Eide et al., 2018). To summarize, we suggest to use the combination of: (1) subparallel, inclined reflections; (2) cross-cutting reflections and (3) unidirectional reflection junctions to identify shear zones in seismic reflection data (Fig. 9).

\subsection{Kinematic indicators}

After identifying a shear zone, we often want to determine its sense of movement. While it is sometimes possible to constrain the sense of movement from the orientation of the shear zone and/or the geological history of the area, we would ideally like to constrain it using kinematic indicators. Our models show that the orientation and curvature of seismic reflections inside the shear zone are consistent with the sense of movement (Figs. 2-8). Seismic reflections forming an acute angle with the edge of the shear zone indicate movement towards that junction (Fig. 10). When looking at a shear zone in map view, seismic reflections curved to right (left) at the top indicate dextral (sinistral) movement and vice versa. This simple geometric relationship, which is consistent with outcrop observations (e.g. Ramsay, 1980), can help us identify the sense of movement of shear zones in seismic reflection data.

\section{Kinematic indicators}
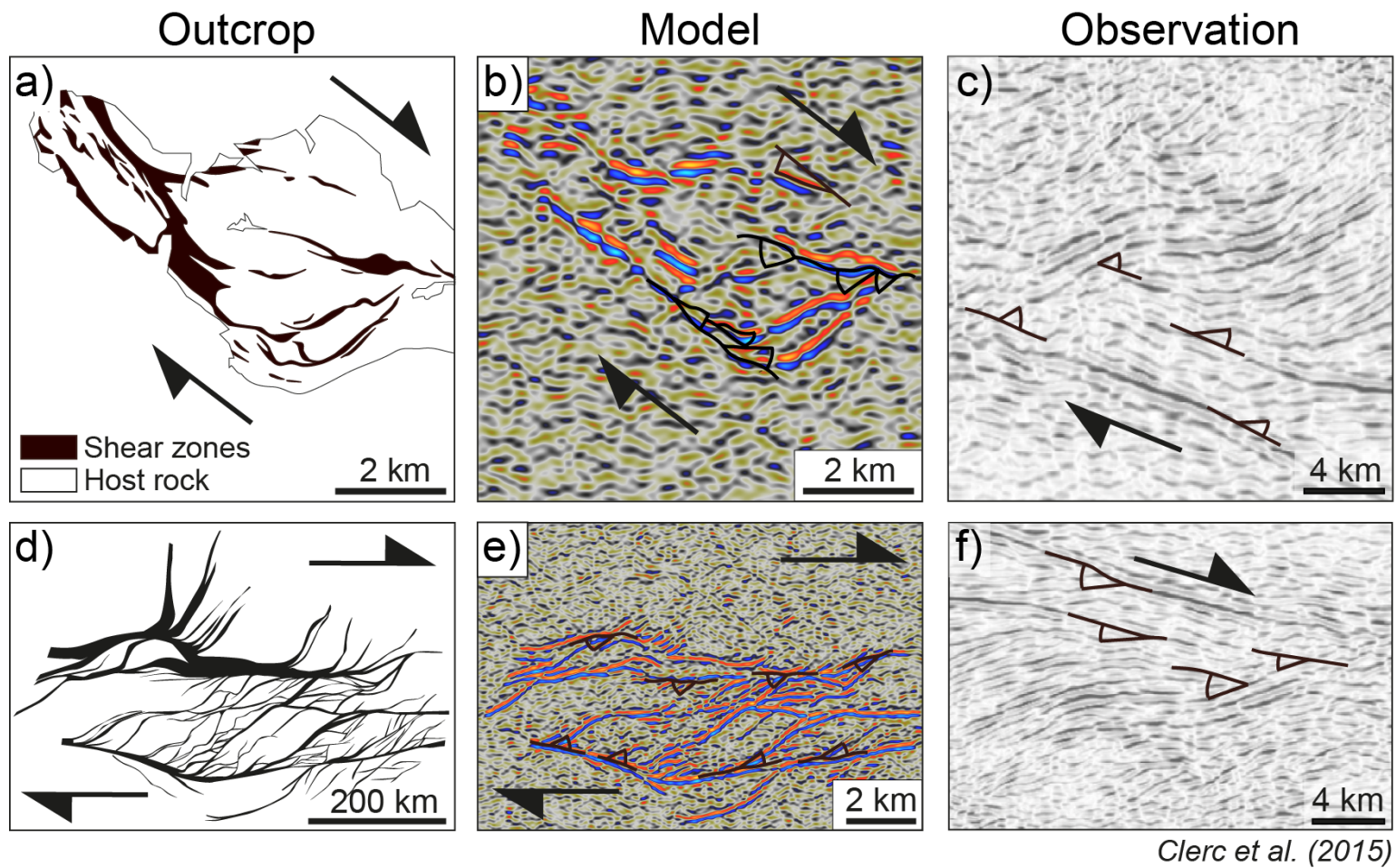

Figure 10: Kinematic indicators showing the sense of movement of: a) Holsnøy shear zone network (Norway), b) the model of the Holsnøy shear zone network, c) shear zone on the Uruguayan margin (Clerc et al., 2015), d) Borborema shear zone network (Brazil), e) the model 
of the Borborema shear zone network, f) shear zone on the Uruguayan margin (Clerc et al., 2015). Note that the direction reflections curve at the shear zone margin indicate the sense of movement.

\subsection{Hidden structures}

While we often concentrate on the shear zones, we see in seismic reflection data, it is also worth highlighting when we might not see them. Our models, for example, show that shear zones become very difficult to image when $50 \%$ of data is noise (Fig. 5g-i). This result is important to remember when discussing the total strain in a system, as large fractions of the strain might not be imaged by seismic reflection data. Similarly, it is difficult to image shear zones dipping steeper than the illumination of the seismic survey (Figs. 6-8). Combining these results with the general trend that illumination decreases with depth, it becomes extremely difficult to image steep structures in the lower crust.

\subsection{Geological complexity}

When generating these large-scale models, it was not possible to include the entire complexity observed in the field. For example, we built these models using only two rock types: shear zones and host rock, which are already difficult to constrain by physical measurements (see Tab. 2). In nature, these rocks are highly variable in terms of composition, metamorphic grade and degree of deformation (e.g. Austrheim et al., 1997; Neves and Mariano, 1999; Carreras, 2001). To include all these elements in seismic models, we would need accurate, high resolution physical measurements of these rocks. Furthermore, we have built these models using current physical rock properties measured in the laboratory, which may differ from those encountered in the subsurface, where pressures, temperatures and pore fluids are different and probably change with time. Finally, it is worth mentioning that it was not possible to include microscopic structures, such as foliation, fractures and veins in these largescale models.

\subsection{Geophysical limitations}

Geophysical effects, we do not investigate in this study, include seismic velocity anisotropies, which are expected to occur in shear zones (e.g. Godfrey et al., 2000; Wenning et al., 2018), but cannot be constrained given the size and complexity of these outcrop examples and the absence of in-situ physical property measurements. With regards to amplitudes, our models simulate perfect processing removing all effects of geometrical spreading, attenuation and dispersion. In nature, these effects are expected to reduce the overall imaging quality. Finally, it is worth emphasizing that we, similar to most field- and seismic studies, approach a 3 -D problem with $2-\mathrm{D}$ models. While generating synthetic $3-\mathrm{D}$ seismic reflection data is possible, it would require large-scale 3-D outcrop observations to generate these models.

\section{Conclusions}

Simulating the seismic signature of three outcrops of shear zones (Holsnøy, Cap de Creus and Borborema), we find that three characteristic features consistently occur in our models: (1) multiple, inclined reflections, (2) converging reflections and (3) cross-cutting reflections. While these features are clear in most cases, they become difficult to recognize when shear zones are dipping steeper than the illumination of the seismic survey or when $50 \%$ of the data consists of noise. We also find that reflection curvature at the shear zone edge is a useful kinematic indicator, as seismic reflections forming an acute angle with the edge of the shear zone correspond to the direction of movement towards the junction.

\section{Acknowledgements}

Financial support for this project was provided by The Norwegian Academy of Science and Letters (VISTA) and The University of Bergen. Furthermore, we thank NORSAR for the permission to use SeisRoX Pro 2018 and Leo Zijerveld for IT support. 


\section{References}

Archanjo, C. J., Trindade, R. I., Bouchez, J. L., and Ernesto, M. (2002). Granite fabrics and regional-scale strain partitioning in the serid belt (borborema province, ne brazil). Tectonics, 21(1):3-1-3-14.

Austrheim, H. (1987). Eclogitization of lower crustal granulites by fluid migration through shear zones. Earth and Planetary Science Letters, 81(2-3):221-232.

Austrheim, H. (1990). The granulite-eclogite facies transition: A comparison of experimental work and a natural occurrence in the bergen arcs, western norway. Lithos, 25(1-3):163-169.

Austrheim, H., Erambert, M., and Engvik, A. K. (1997). Processing of crust in the root of the caledonian continental collision zone: the role of eclogitization. Tectonophysics, 273(12):129-153.

Austrheim, H. and Griffin, W. L. (1985). Shear deformation and eclogite formation within granulite-facies anorthosites of the bergen arcs, western norway. Chemical Geology, 50(13):267-281.

Bingen, B., Austrheim, H., Whitehouse, M. J., and Davis, W. J. (2004). Trace element signature and $\mathrm{u}-\mathrm{pb}$ geochronology of eclogite-facies zircon, bergen arcs, caledonides of $\mathrm{w}$ norway. Contributions to Mineralogy and Petrology, 147(6):671-683.

Boundy, T., Fountain, D., and Austrheim, H. (1992). Structural development and petrofabrics of eclogite facies shear zones, bergen arcs, western norway: implications for deep crustal deformational processes. Journal of Metamorphic Geology, 10(2):127-146.

Bourbi, T., O. C. and Zinszner, B. (1987). Acoustics of porous media: Gulf Publ. translated by N. Marshall from French, Acoustique des Milieux Poreu (1987).

Carreras, J. (2001). Zooming on northern cap de creus shear zones. Journal of Structural Geology, 23(9):1457-1486.

Clerc, C., Jolivet, L., and Ringenbach, J.-C. (2015). Ductile extensional shear zones in the lower crust of a passive margin. Earth and Planetary Science Letters, 431:1-7.

de Castro, D. L., Bezerra, F. H., and Branco, R. M. C. (2008). Geophysical evidence of crustalheterogeneity control of fault growth in the neocomian iguatu basin, ne brazil. Journal of South American Earth Sciences, 26(3):271-285.

de Castro, D. L., Bezerra, F. H., Sousa, M. O., and Fuck, R. A. (2012). Influence of neoproterozoic tectonic fabric on the origin of the potiguar basin, northeastern brazil and its links with west africa based on gravity and magnetic data. Journal of Geodynamics, 54:29-42.

Eide, C. H., Schofield, N., Lecomte, I., Buckley, S. J., and Howell, J. A. (2018). Seismic interpretation of sill complexes in sedimentary basins: implications for the sub-sill imaging problem. Journal of the Geological Society, 175(2):193-209.

Fazlikhani, H., Fossen, H., Gawthorpe, R. L., Faleide, J. I., and Bell, R. E. (2017). Basement structure and its influence on the structural configuration of the northern north sea rift. Tectonics, 36(6):1151-1177.

Fossen, H. (1993). Structural evolution of the bergsdalen nappes, southwest norway. Norges geologiske underskelse Bulletin, 424:23-50. 
Fossen, H. (2010). Extensional tectonics in the north atlantic caledonides: a regional view. Geological Society, London, Special Publications, 335(1):767-793.

Fossen, H. and Cavalcante, G. C. G. (2017). Shear zones-a review. Earth-Science Reviews, 171:434-455.

Fossen, H. and Hurich, C. A. (2005). The hardangerfjord shear zone in sw norway and the north sea: a large-scale low-angle shear zone in the caledonian crust. Journal of the Geological Society, 162(4):675-687.

Foster, D. A., Goscombe, B. D., and Gray, D. R. (2009). Rapid exhumation of deep crust in an obliquely convergent orogen: the kaoko belt of the damara orogen. Tectonics, 28(4).

Ganade de Araujo, C. E., Weinberg, R. F., and Cordani, U. G. (2014). Extruding the borborema province (ne-brazil): a two-stage neoproterozoic collision process. Terra Nova, 26(2):157-168.

Gapais, D., Bale, P., Choukroune, P., Cobbold, P., Mahjoub, Y., and Marquer, D. (1987). Bulk kinematics from shear zone patterns: some field examples. Journal of Structural Geology, $9(5): 635-646$.

Godfrey, N., Beaudoin, B., and Klemperer, S. (1997). Ophiolitic basement to the great valley forearc basin, california, from seismic and gravity data: Implications for crustal growth at the north american continental margin. Geological Society of America Bulletin, 109(12):15361562 .

Godfrey, N. J., Christensen, N. I., and Okaya, D. A. (2000). Anisotropy of schists: Contribution of crustal anisotropy to active source seismic experiments and shear wave splitting observations. Journal of Geophysical Research: Solid Earth, 105(B12):27991-28007.

Gontijo-Pascutti, A., Bezerra, F. H., La Terra, E., and Almeida, J. C. (2010). Brittle reactivation of mylonitic fabric and the origin of the cenozoic rio santana graben, southeastern brazil. Journal of South American Earth Sciences, 29(2):522-536.

Goscombe, B., Hand, M., and Gray, D. (2003). Structure of the kaoko belt, namibia: progressive evolution of a classic transpressional orogen. Journal of Structural Geology, 25(7):1049-1081.

Goscombe, B. D. and Gray, D. R. (2008). Structure and strain variation at mid-crustal levels in a transpressional orogen: a review of kaoko belt structure and the character of west gondwana amalgamation and dispersal. Gondwana Research, 13(1):45-85.

Hansen, D. M., Cartwright, J. A., and Thomas, D. (2004). 3d seismic analysis of the geometry of igneous sills and sill junction relationships. Geological Society, London, Memoirs, 29(1):199208.

Johnston, S., Hacker, B. R., and Ducea, M. N. (2007). Exhumation of ultrahigh-pressure rocks beneath the hornelen segment of the nordfjord-sogn detachment zone, western norway. GSA Bulletin, 119(9-10):1232-1248.

Kirkpatrick, J., Bezerra, F., Shipton, Z., Do Nascimento, A., Pytharouli, S., Lunn, R., and Soden, A. (2013). Scale-dependent influence of pre-existing basement shear zones on rift faulting: a case study from ne brazil. Journal of the Geological Society, 170(2):237-247.

Klepeis, K. A., Daczko, N. R., and Clarke, G. L. (1999). Kinematic vorticity and tectonic significance of superposed mylonites in a major lower crustal shear zone, northern fiordland, new zealand. Journal of Structural Geology, 21(10):1385-1405. 
Koehn, D., Link, K., Sachau, T., Passchier, C., Aanyu, K., Spikings, A., and Harbinson, R. (2016). The rwenzori mountains, a palaeoproterozoic crustal shear belt crossing the albertine rift system. International Journal of Earth Sciences, 105(6):1693-1705.

Labrousse, L., Hetényi, G., Raimbourg, H., Jolivet, L., and Andersen, T. B. (2010). Initiation of crustal-scale thrusts triggered by metamorphic reactions at depth: Insights from a comparison between the himalayas and scandinavian caledonides. Tectonics, 29(5).

Lecomte, I. (2008). Resolution and illumination analyses in psdm: A ray-based approach. The Leading Edge, 27(5):650-663.

Lecomte, I., Lavadera, P. L., Anell, I., Buckley, S. J., Schmid, D. W., and Heeremans, M. (2015). Ray-based seismic modeling of geologic models: Understanding and analyzing seismic images efficiently. Interpretation, 3(4):SAC71-SAC89.

Lecomte, I., Lavadera, P. L., Botter, C., Anell, I., Buckley, S. J., Eide, C. H., Grippa, A., Mascolo, V., and Kjoberg, S. (2016). 2 (3) d convolution modelling of complex geological targets beyond-1d convolution. First Break, 34(5):99-107.

Magee, C., Jackson, C. A.-L., and Schofield, N. (2014). Diachronous sub-volcanic intrusion along deep-water margins: insights from the irish rockall basin. Basin Research, 26(1):85-105.

Mainprice, D. and Casey, M. (1990). The calculated seismic properties of quartz mylonites with typical fabrics: relationship to kinematics and temperature. Geophysical Journal International, 103(3):599-608.

Manghnani, M. H., Ramananantoandro, R., and Clark, S. P. (1974). Compressional and shear wave velocities in granulite facies rocks and eclogites to $10 \mathrm{kbar}$. Journal of Geophysical Research, 79(35):5427-5446.

Milnes, A., Wennberg, O., Skår, Ø., and Koestler, A. (1997). Contraction, extension and timing in the south norwegian caledonides: the sognefjord transect. Geological Society, London, Special Publications, 121(1):123-148.

Neves, S. P. and Mariano, G. (1999). Assessing the tectonic significance of a large-scale transcurrent shear zone system: the pernambuco lineament, northeastern brazil. Journal of Structural Geology, 21(10):1369-1383.

Norton, M. (1986). Late caledonide extension in western norway: A response to extreme crustal thickening. Tectonics, 5(2):195-204.

Osagiede, E. E., Duffy, O. B., Jackson, C. A.-L., and Wrona, T. (2014). Quantifying the growth history of seismically imaged normal faults. Journal of Structural Geology, 66:382-399.

Passchier, C., Trouw, R., Ribeiro, A., and Paciullo, F. (2002). Tectonic evolution of the southern kaoko belt, namibia. Journal of African Earth Sciences, 35(1):61-75.

Phillips, T. B., Jackson, C. A., Bell, R. E., Duffy, O. B., and Fossen, H. (2016). Reactivation of intrabasement structures during rifting: A case study from offshore southern norway. Journal of Structural Geology, 91:54-73.

Phillips, T. B., Magee, C., Jackson, C. A., and Bell, R. E. (2018). Determining the threedimensional geometry of a dike swarm and its impact on later rift geometry using seismic reflection data. Geology, 46(2):119-122.

Planke, S., Rasmussen, T., Rey, S. S., and Myklebust, R. (2005). Seismic characteristics and distribution of volcanic intrusions and hydrothermal vent complexes in the vøring and møre basins. Geological Society, London, Petroleum Geology Conference series, 6(1):833-844. 
Ramsay, J. (1980). Shear zone geometry: A review. Journal of Structural Geology, 2(1):83 99. Shear zones in rocks.

Salomon, E., Koehn, D., and Passchier, C. (2015). Brittle reactivation of ductile shear zones in nw namibia in relation to south atlantic rifting. Tectonics, 34(1):70-85.

Sheriff, R. E. and Geldart, L. P. (1995). Exploration seismology. Cambridge university press.

Wennberg, O. P., Milnes, A. G., and Winsvold, I. (1998). The northern bergen are shear zone an oblique-lateral ramp in the devonian extensional detachment system of western norway. Norsk Geologisk Tidsskrift.

Wenning, Q. C., Madonna, C., de Haller, A., and Burg, J.-P. (2018). Permeability and seismic velocity anisotropy across a ductile-brittle fault zone in crystalline rock. Solid Earth, 9(3):683698.

Yilmaz, Ö. (2001). Seismic data analysis: Processing, inversion, and interpretation of seismic data. Society of exploration geophysicists.

Younes, A. I. and McClay, K. (2002). Development of accommodation zones in the gulf of suez-red sea rift, egypt. AAPG bulletin, 86(6):1003-1026. 